研究

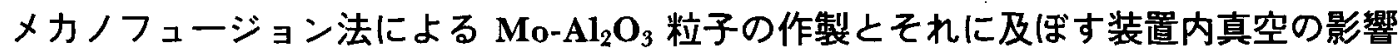

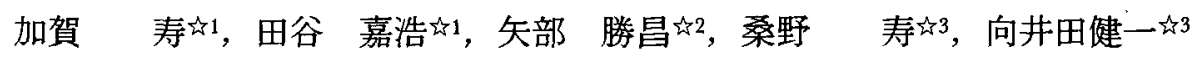

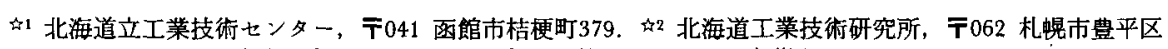 \\ 月寒東 2 条17丁目2-1。和室蘭工業大学, 于050 室闌市木元町27-1.
}

\title{
Preparation of $\mathrm{Mo}-\mathrm{Al}_{2} \mathrm{O}_{3}$ Particles by Mechanofusion Process and Effects of Reduced Equipment Pressure on it
}

\author{
Hisashi Kaga ${ }^{\star 1}$, Yoshihiro Taya ${ }^{\star 1}$, Katsumasa Yabe ${ }^{\star 2}$

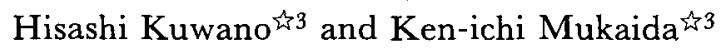

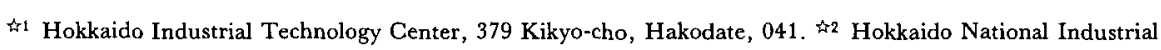 \\ Research Institute, 2-17 Tsukisamu-Higashi, Toyohira-ku, Sapporo 062. 解 Muroran Institute of Technology, \\ 27-1 Mizumoto-cho, Muroran, 050.
}

Received December 14, 1994

\section{SYNOPSIS}

Using the vacuum mechanofusion apparatus which has been reported in this journal. the formation of Mo composite with $\mathrm{Al}_{2} \mathrm{O}_{3}$ core particles was conducted. The effects of the surrounding pressure on both of the processing behavior and the characteristics of the composite particles were discussed from the data of the specific surface area, particle size distibution and from the results of SEM observation, XPS and AES analyses.

The formation of composite particles progressed with processing time. As surrouding pressure decreased, the yield of formation was found to increase and the Ho coated surface became smoother. XPS analysis for Mo coated layer revealed that the thickness of oxide layer became thicker. While, AES elucidated that 0 content and its enriched depth in Mo coated layer formed under high vacuum was lower and shallower respectively than those formed in the air atmosphere.

\section{KEY TORDS}

Mo- $\mathrm{Al}_{2} \mathrm{O}_{3}$ system, mechanofusion, vacuum, composite particle, surface analysis.

\section{1 緒 言}

表面反応を利用する触媒，組織制御や粒界を利用 する高機能複合焼結材料の作製において，被覆型複 合粒子の応用が期待されている. 近年, この粒子複 合化に関する技術開発が急激に進みつつある。なか でも，機械的エネルギーを粒子に付与し，複合化さ せるメカノケミカル反応を利用した乾式複合化プロ セスは，污染が少なくかつその取扱の容易さ等から 注目されている.このプロセスの一つに, ケーシン グとインナーピース間で高せん断応力を付与し，粒 子を複合化させるメカノフュージョン法がある.同 法は、材料に対する汎用性, プロセスの単純さなら びに複合化の容易性等の観点から工業化が期待され, その研究も多(1-3).

筆者らはこれまでに核粒子 $\mathrm{Al}_{2} \mathrm{O}_{3}$ へのCu粒子の複
合化試験を行い，真空下の処理により複合化が著し 〈促進されることを明らかにしだ〉。複合化処理中 粒子は力を受けつつ相互に運動している．その初期 過程において，軟らかいCu粒子が硬い $\mathrm{A}_{2} \mathrm{O}_{3}$ 表面へ の移着を繰り返す，いわゆる凝着摩耗が複合化に対 し非常に重要な役割りを果たすとの知見を得た5)。

本研究では，硬質・低延性でかつ酸化に対する感 受性の高いMo粒子の $\mathrm{A}_{2} \mathrm{O}_{3}$ 粒子への複合化を行ない， 複合化に対する真空中処理の影響について明らかに した．さらに，複合粒子の表面分析を行ない，真空 中の処理の効果についても检討を加えた。

\section{2 実驗方法}

試験に用いたメカノフュージョシ装置の詳細は 前報ら〉に記したとおりである。回転するケーシン 
グと固定のインナーピース等から構成されていて， ケーシングを直接排気する構造である.チャンバ内 は $10^{-2} \mathrm{~Pa}$ の高真空保持下での稼働が可能である.

試験に用いた粉末は，核粒子としては前報51と同 様の平均粒子径 $45 \mu$ 田の（株）マイクロン製球形 $\mathrm{Al}_{2} \mathrm{O}_{3}$ 粒子, 付着粒子としては平均粒子径 $0.6 \mu \mathrm{m}$ の 日本新金属（株）製粗子を用いた。. $\mathrm{A}_{2} \mathrm{O}_{3}$ 粒子は， $\alpha-\mathrm{A}_{2} \mathrm{O}_{3}$ をプラズマ中で加熱し，球形化したもの であり，Mo粒子は水素還元法により作製された粒状 の粉末であった。

これら $\mathrm{Al}_{2} \mathrm{O}_{3}$ 粒子全表面をMo粒子 1 層の $0.6 \mu \mathrm{m}$ 厚 さにて被覆するとして，被覆に必要な最小のMo量を 算定式 ( $12 \mathrm{mass} \% \mathrm{Mo}-88 \mathrm{mass}_{\mathrm{OAl}} \mathrm{O}_{3}$ (以下 $12 \mathrm{Mo}-88 \mathrm{Al}_{2} \mathrm{O}_{3}$ と 記す)混合粉体 $100 \mathrm{~g}$ をーシング内に装入し， $1.0 \times$ $10^{5}, 1.1 \times 10^{2}, 5.3 \times 10^{-2} \mathrm{~Pa}$ 所定圧力まで排気を 続けた状態にて，メカノフュージョン処理を施した。 高真空の $5.3 \times 10^{-2} \mathrm{~Pa}$ みはメカノフュージョンに より排気能力以上の放出ガスがあるため, 初期の真 空を保持するのが困難であった. したがって，5.3 $\times 10^{-2} \mathrm{~Pa}$ 高真空のみは初期の繁团気压力を, これ 以外は稼㗢中の䇰囲気圧力を示した。

$5.3 \times 10^{-2} \mathrm{~Pa}$ の高真空でのチャンバ内の酸素分圧 は, $8.5 \times 10^{-4} \mathrm{~Pa}$ であり、残留分压の大部分は $\mathrm{H}_{2} 0$, $\mathrm{CO}_{2}$ であった。 メカノフュージョン開始とともに, これら吸着ガスの急激な脱離を生じだ，主要なメ カノフュージョン条件としては(1)ケーシングの回転 速度 $900 \mathrm{rpm}$, (2)ケーシングとインナーピースとの 間隔 $3.5 \mathrm{~mm}$ 。 (3)メカノフュージョン処理時間 $0 \sim 3.6$ ksとした。

複合化の進行にともない，粉体の比表面積が咸少 することが知られているので8)，メカノフュージョ ン前後の複合粉末について，島津（株）製マイクロ ソーブ 2300 を用い，B E T一点法により比表面積を 測定した。 また、へキサメタりン酸りーダ水溶液中 にて0.6 ks超音波分散後. Marvern製レーザ回折 式Mastersizer MS20 にで粒度分布測定を行なった。 このメカノフュージョン前後の粒度分布の差から。 複合化されない付着粒子の体積率を求め，これを未 複合化粒子の体皘率とした．

複合粒子についてSEM観察，X線光電子分光分析 (XPS)およびオージェ電子分光分析(AES)を行なった. XPS装置はKratos製 XSAM-800，AES装置は日本電子

（株）JAMP-7000を使用した。

\section{3 実験結果およひ検討}

\section{1 真空霝囲気の影響}

$12 \mathrm{Mo}-88 \mathrm{Al}_{2} 0_{3}$ 混合粉体について，異なった霣囲 気尤力下にてメカノフュージョン処理を行なった. その処理時間にともなうインナーピース温度，BET 比表面積ならびに未複合化粒子の体皘率の変化を排 気後のチャンバ内の需囲気圧力（残留圧力）にて整 理し，Fig. 1に示した。メカノフュージョン時間の 增加にともないB E T比表面積は減少した。その減少

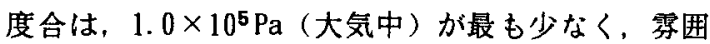
気圧力が減少するほど比表面積の減少度合は大きか った．末複合化粒子の体積率の処理時間ならびに霛 囲気圧力に対する傾向もBET比表面積と全く同一の 挙動を示すことが明らかとなった。このように低雾 囲気圧力ほど複合化の進行度合が大きくなることが わかった，複合化進行の評洒法としての比表面積と 未複合化粒子の体積率との関連性について検討した 結果，これら両者にきわめて良い相関関係を有する ことが知られた。

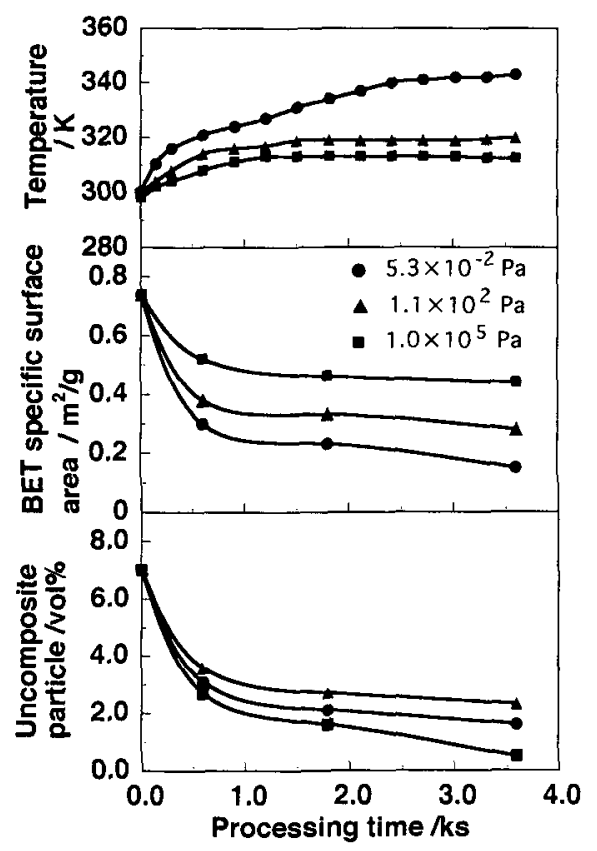

Fig. 1 Change of inner piece temperature, specific surface area and volume percent of uncom - posite particle with processing time, as a function of residual pressure.

インナーピース温度は，メカノフュージョン処理 時間の增加とともに上昇し，その後一定となった。 
その上昇度合は需囲気圧力により異なり， $5.3 \times$ $10^{-2} \mathrm{~Pa}$ (高真空）が最も温度上昇が大きく，1.1× $10^{2} \mathrm{~Pa}$ (低真空), $1.0 \times 10^{5} \mathrm{~Pa}$ の順となった. メ力 ノフュージョン処理中のインナーピースに作用する 圧縮力, 曲げ等の力学的計測の結果, 雾囲気圧力が 低いほど大きな力が発生し, 消費電力も大きいこと が明らかとなった 囲気圧力ほど投入されているエネルギーが大きく， かつ昇温した粒子表層を冷却する気体分子が少ない ことから, 結果的に高温となったと推察された.

$5.3 \times 10^{-2} \mathrm{~Pa}$ に $0.9 \sim 10.8 \mathrm{ks}$ 間メカノフュージョ ン後の複合粒子の外観をFig. 2に示した.（a）の0.9 $\mathrm{ks}$ 短時間処理においてもMo粒子は, 核粒子 $\mathrm{Al}_{2} \mathrm{O}_{3}$ の 全表面を完全に被覆していた．しかし，Mo粒子の付 着にともなう突起も大きく，かつ多数のMo未複合化 粒子が散在していた（b ) $1.8 \mathrm{ks}$ においては，突起 部が若干少なくなるとともに，未複合化粒子も少な

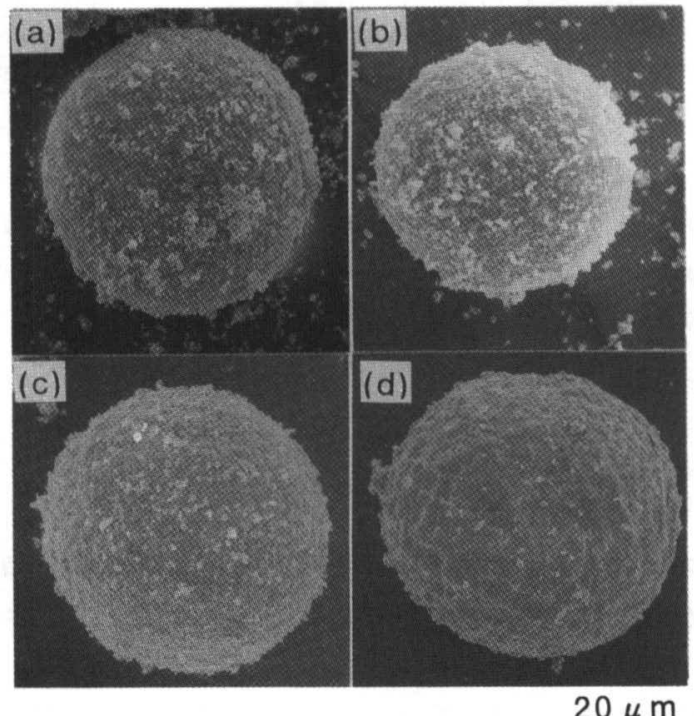

Fig. 2 Secondary electron micrographs of appearance composite particles formed with processing time of $0.9 \mathrm{ks}(\mathrm{a}), 1.8 \mathrm{ks}(\mathrm{b}), 3.6 \mathrm{ks}(\mathrm{b})$ and $10.8 \mathrm{ks}(\mathrm{d})$, respectively.

くなり複合化が進んでいる様相を呈していた（ c ） $3.6 \mathrm{ks}$ においては, 粒子の突起部はさらに少なくな るとともに，末複合化粒子はほとんど観察できず， 一段之複合化が進んだ様子がわかった，さらに長時 間の ( d )10.8ksについていは参考のために比較用と して示した（ $\mathrm{a}$ )から ( c )までの短時間の場合と全
く異なった様相を呈していた．表面は丹野等が提起 しているようにシェル化した被覆層を形成し2)，Mo 粒子と全く異なった粒子表面の状況として観察され， より強固な接合の被覆層が形成されているものと推 定した。

3. $6 \mathrm{ks}$ メノフュージョン後の $12 \mathrm{Mo}-88 \mathrm{Al}_{2} \mathrm{O}_{3}$ 複合 粒子の表面状況におよぼす雲囲気圧力の影響につい

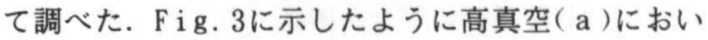
てはMo粒子が偏平・粗大化し, 平滑状況を示し,よ り複合化が進行している様相を呈していた.これに 対し, 大気中 ( c )ではMo粒子が粒状で小さく, 凹凸 が大きな表面状態であり，複合化の進行度合も低い ことがわかった. 低真空 ( b ) では高真空と大気中の 中間の表面状況を呈していた．大気中のメカノフュ ージョンの場合には, 雲囲気からの酸化または固溶 酸素の増加等により, Mo展延性が損なわれるため, 偏平になりずらかったと考えられた。

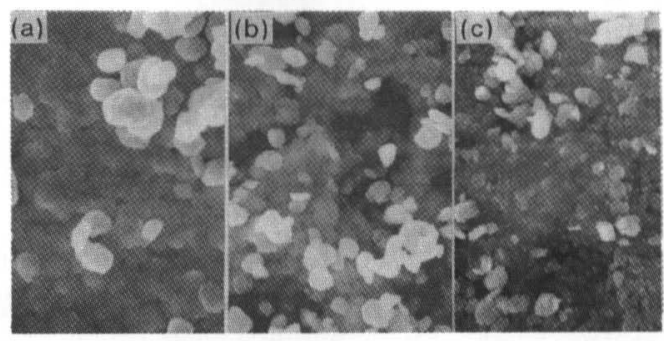

$2 \mu \mathrm{m}$

Fig. 3 SEM microphotographs of the surfaces of of mechanofused particles under high vacuum (a), low vacuum (b), and in the air atmosphere (c), respectively. All specimens were treated for same time of $3.6 \mathrm{ks}$.

\section{2 複合粒子の接合性}

圧力の異なった雲囲気下で $3.6 \mathrm{ks}$ メノフュージ ョン後の複合粉体について、ヘキサメタリン酸ソー ダ水溶液中で $0.18 \sim 0.8 \mathrm{ks}$ 超音波分散を行ない, こ の分散時間に対するMoの剥離粒子の体積率の変化を 求めた. メカノフュージョンの雲囲気圧力により超 音波分散の初期段階における剥離粒子の体積率が異 なり, 雾囲気圧力が低いほど剥離粒子の体積率が少 なく，強固な複合化が起こっていることを示した． さらに超音波分散時間を増加させると、いずれの雲 囲気圧力の複合粉体とも Fig. 4から明らかなように 徐々に剥離粒子の体積率が増加し, その後一定とな り変化しないことがわかった。 
この低真空処理と高真空，大気中処理との分散時 間に対する举動の差異については明らかではない. しかし，前報のCu被覆の場合，超音波分散時間とと もに剥離粒子の体積率が增加傾向にあり，超音波 分散時間による剥離粒子の体皘率の増加度合も大 きく、その举動とFig.40結果は明らかに異なって (だ)。Cu被覆首に比べHoの方がA $1_{2} \mathrm{O}_{3}$ との接合な らびに付着粒子間の接合が強固であるとも考えらた が，明確な理由については現状では明らかでない。

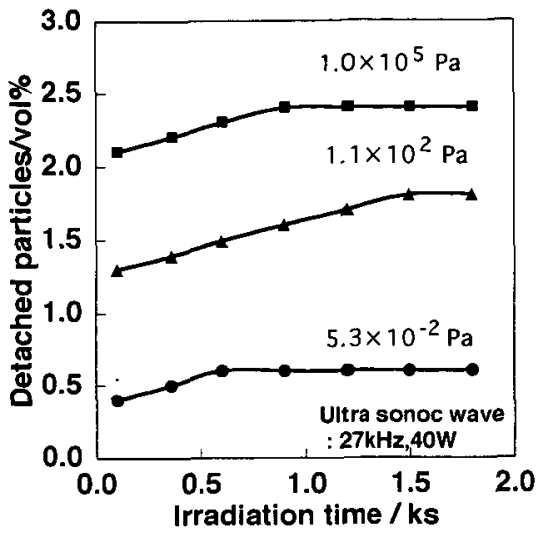

Fig. 4 . Detachment ratios of particles due to ultrasonic wave irradiation from the coated layers of composite particles mechanofused for $3.6 \mathrm{ks}$ under several pressures.

\section{3 複合粒子の表面分析}

$3.6 \mathrm{ks}$ メノフュージョン後の複合粒子について XPS分析を行なった，複合粒子表層のXPSの実測スぺ クトルと、ピーク分離ならびに合成スペクトルを Fig.5に示した（a)は雲囲気圧力5. $3 \times 10^{-2} \mathrm{~Pa}$,

(b)は1.0×105 Paの結果をそれぞれ示した。実測 データは（一）細線の実線で示されているが 全体には 3 つピークから構成されていた。この実 測スペクトルについて，次の条件でピーク分離を行 なった。

スペクトル成分としては, $\mathrm{Mo}$ (金属)， $\mathrm{MoO}_{2}, \mathrm{MoO}_{\mathrm{x}}$ (2くx<3)， $\mathrm{HOO}_{3}$ を仮定した．金属については実测 スペクトルを，それ以外についてはガウス型ピーク により近似させた，金属の3 $\mathrm{d}_{6} / 2$ のピーク位置よ各 ピーク位直との善は，K.S.K i四等の文献值を用い $た^{18)}$. $3 \mathrm{~d}_{6 / 2} / 3 \mathrm{~d}_{3 / 2}$ の強度比を1.5と仮定した。各 スペクトルを加算合成したスペクトルが実測スペク
トルに゙合致するようなフイッティングを行なった。 このようにピーク分離して求めた個々の分解スペク トルを（‥-…）にて、これらを加算合成したス ペクトルを（一）にて各々示した，高真空中 のFig.5(a)においては低結合エネルギー側の金属 ピークがが主要ピークとして認められたのに対し， ( b )の大気中ではこの金属Moピークがきわめて小さ く、 $\mathrm{MoO}_{\mathbf{x}} 、 \mathrm{MoO}_{3}$ で構成される高エネルギー㑡の酸化 物のピークが主要となっっていた。
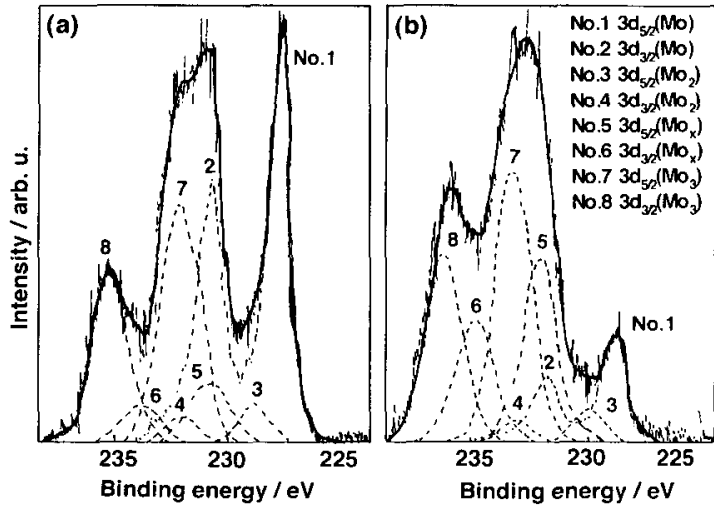

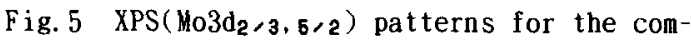
posite particles prepared under the residual pressure of $5.3 \times 10^{-2}(\mathrm{a})$ and $1.0 \times 10^{5} \mathrm{~Pa}(\mathrm{~b})$. Spectra cueves of experimental ( - ) , decomposed (....) and synthesized ( $(-)$ ), respectively.

これら各スペクトル成分間の定量化を図るため， 各スペクトル成分の $3 \mathrm{~d}_{5} / 2$ と $3 \mathrm{dd}_{3} / 2$ との合算の面積 から，その相対面積強度を算定した。この結果を Fig.6に示した．高真空ならびに低真空処理の複合 粒子では，金属の相対面積強度が約 $50 \%$ なに対し， 大気中処理粒子においては，金属が十数\%と低下し ていた，酸化物の中でも， $\mathrm{HoO}_{2}$ の相対面積強度はほ とんど変化しないが, より酸化の価数の大きい $\mathrm{MoO}_{\mathrm{x}}$ と $\mathrm{HOO}_{3}$ が大きくなっていて，特にHoOx の変化が顕著 であった。このように大気中好理により、以o被覆粒 子の酸化が著しく促進されることを示した。

Arイオンにてスパッ夕を行ないつつ, XPS分析を 行なった.この結果はFig.7に示したとおりである. スパッ夕条件はArイオンエネルギー $2 \mathrm{kV}$ ，イオン電 流密度は7 $\mu \mathrm{A} / \mathrm{cm}^{2}$ とした. Fig. 7( a )は算囲気圷力

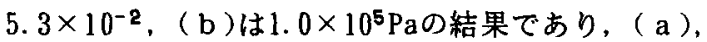


( b )ともスペクトルの最下段が金属のピークに対応 していた（a)の高真空処理の椱合粒子においては,

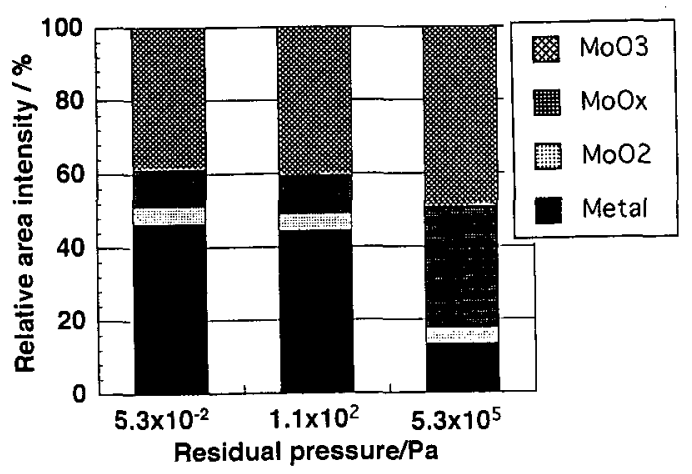

Fig. 6 Relative area intensity of XPS vs. residual pressure under which the composite particles were prepared.

スパッ夕時間 $180 \mathrm{~s} て ゙ 1200 \mathrm{~s}$ 長時間スパッタと同様 の金属スペクトルとなっていた．これに対し，（b） の大気中処理ではこの金属ピークを示すのはスパッ 夕時間480sからであり，それだけ酸化物層が厚く なっていることを示していた．したがって，Fig.7 において，大気処理のMo被覆層の酸化物の相対面皘 強度が大きいのは，酸化物層が厚いためと考えられ， その分金属の相対面積強度が低下していた。
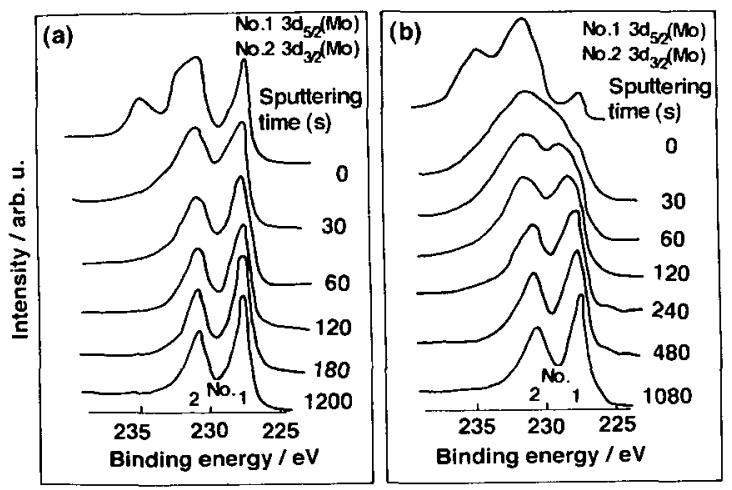

Fig. 7 XPS $\left(\operatorname{Mo}_{0} \mathrm{~d}_{2}, 3,6,2\right)$ levels measured changing sequentially sputtering time, for the com - posite particles prpared under the residual pressure of $5.3 \times 10^{-2} \mathrm{~Pa}(\mathrm{a})$ and $1.0 \times 10^{5} \mathrm{~Pa}(\mathrm{~b})$.

$5.3 \times 10^{-2} \mathrm{~Pa}$ 政 $6 \mathrm{ks}$ メカフュージョン後の複 合粒子のAESスペクトルをFig. 8に示した。付着粒子
のMo以外にC，0，A1のピークが検出された，前報の Cuの場合と全く同じ結果であり ${ }^{5}$ ，Cは有機系不純 物による污染が考えられた。A1ピークは核粒子に関 連するAl_03によると考えられた．Arイオンをスパ ッタしつつA 1 ピークに注目して分析した結果，核粒 子A $1_{2} \mathrm{O}_{3}$ に到達する前の中間段階において，A1がほ とんど検出できなくなることから，核粒子のA $1_{2} \mathrm{O}_{3}$ 現出部からのA1ではないと判断した。

したがって，以o付着粒子の被覆層の中に微細な $\mathrm{A}_{2} \mathrm{O}_{3}$ 粒子が混在している状況を示した。メ力ノ フュージョン初期段階で核粒子間の同体摩擦，また

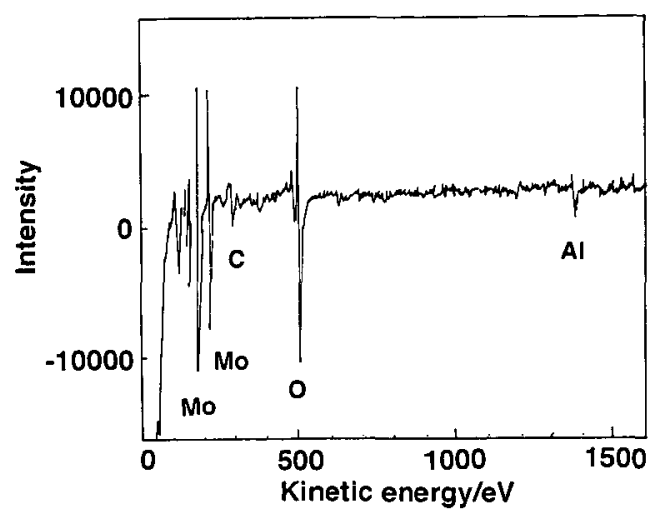

Fig. 8 AES spectrum of surface for composite particle prepared under $5.3 \times 10^{-2} \mathrm{~Pa}$.

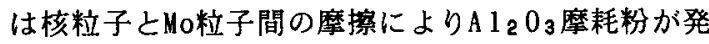
生した，Mo付着粒子の核粒子の接合，または付着粒 子間の接合による被覆首形成段階で, 硬い $\mathrm{Al}_{2} \mathrm{O}_{3}$ が Mo被覆層に押し込まれたと考えた。Cu被覆層におい ても全く同様の現象が確認された。

0 ピークについてはA $1_{2} \mathrm{O}_{3}$ と，Mo酸化物またはMo 中に固溶する00いずれかの状態を示した。この0の Mo被覆層内の分布を明らかにするため，Arイオンに てスパッタを行ないつつ00分析を行なった，AES分 析ならびスパッター条件は前報ら)と同一条件と した，前述のようにMo被蕧層内にA $1_{2} \mathrm{O}_{3}$ が含有され

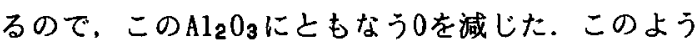
にして求めた0の深さ方向の分布をFig.9に示した。

Fig. 9の○印は雰囲気王力 $5.3 \times 10^{-2} \mathrm{~Pa}$ 結果を， A印は大気中の結果を各々示した。の印の真空中に

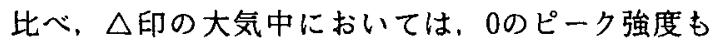
大きく，かつ0がHo被覆層の内部まで濃化している ことを示した。このAESによる00分布に関する結果 
は, 前述のFig. 5〜 7のXPS分析結果を0分布の形で哀 付けていた.

メカノフュージョン中に粒子間の摩擦により粒子 表層が著しく高温となった．先のCuの焼結挙動から 粒子表層の昇温に関する研究では1000亿前後までの 温度上昇を来すとの研究結果を得だ1)，野城のMo の酸化挙動からの昇温に関する研究においても, 593〜1703Kの温度上昇としていだ21．大気中にお いては、この表層の発熱とともに大気雾囲気からの 0によりMo表面が酸化または酸素吸収が一段と進ん だと考えられた。したがって，真空中にてメカノ

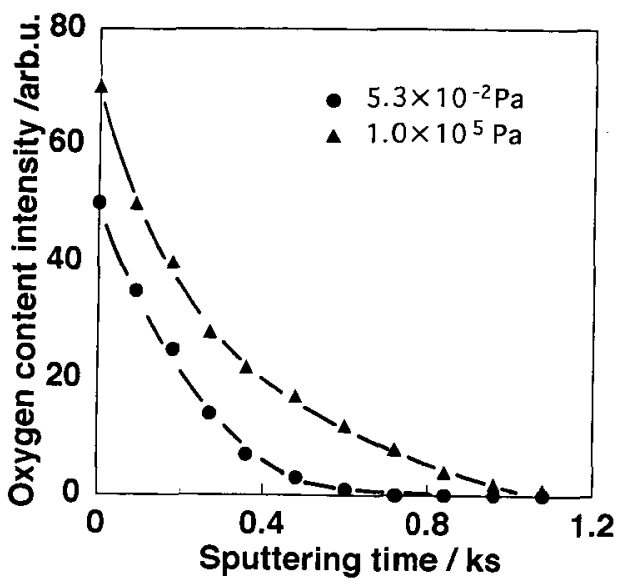

Fig. 9 Variation of 0xygen peak intensity of AES with sputtering time, for the composite particles formed under different pressures.

フュージョン処理を行なうと，粒子表層の酸化が 㧕制され，酸化が激しい大気中処理の場合に比べ, Mo粒子間ならびにMoと $\mathrm{Al}_{2} \mathrm{O}_{3}$ 粒子間に強固な接合を 生じ，結果的に複合化が促進されたと考えられた。

\section{4 結 言}

真空メカノフュージョンを用いた，核粒子 $\mathrm{Al}_{2} \mathrm{O}_{3}$ 。 付着粒子Moの複合粒子形成とその複合粒子の表面分 析に関する試験より以下の知見を得た。

1. 複合粒子の形成に対し真空の効果はきわめて大き く，雲囲気圧力が低いほど，複合化が進行すると ともにインナーピース温度も高かった。

2. 高真空下にて処理した複合粒子のMo被敏層が平滑 であるのに対し、大気中処理では凹凸が大きく， かつMoの変形が少なく微細化していた.
3. 複合粒子のXPS分析の結果, Mo被覆層はMo(金属), $\mathrm{MoO}_{2}, \mathrm{MoO}_{\mathbf{x}}, \mathrm{HoO}_{3}$ の酸化物から構成されているこ とが明らかとになった．また，作製された雾囲気 殴力によりこれら酸化物のスペクトル成分の面積 強度が異なり，大気中処理ではMoOx，Mo03の面積 強度が高かった。

4. 大気中処理の粒子の方が真空中処理に比べＸPS 分析の結果では $\mathrm{Mo}^{2}$ 被覆層内の $\mathrm{MoO}_{\mathbf{x}}, \mathrm{MoO}_{3}$ の酸化物 層も厚く，かつA ES分析の結果では酸素濃度は高 く，その濃化深さも深かった。

\section{謝 辞}

本研究のAES分析に協力いただいた北海道立工業 技術センタ一营原智明研究員に心より謝意を表しま す.

\section{文献}

1) K. Tsuji, H. Inada and K. Kojima, M. Satoh,

K. Higashi, K. Miyanami and S. Tanimura

:J. Mater. Sci., 27(1992), 1179.

2）丹野浩一, 横山藤平：粉体工学会誌, $27(1990), 153$.

3）仙名 保：接着協会誌：23(1987)，20.

4）加賀寿, 田谷嘉浩, 片山博, 濱口由和：粉体 および粉末治金、39(1992)，546.

5）加賀毒，田谷嘉浩，下野功，片山博：粉体お よび粉末治金，39(1992)，1124.

6) Makio Naito, Akira Kondo and Toyokazu Yokoyama:ISIJ International, 33(1993). 915.

7）加賀寿, 田谷嘉浩, 片山博, 濱口由和：粉体 および粉末冶金，39(1992)，553.

8）内藤牧男, 吉川雅浩, 田中俊成, 近藤光：粉 体工学会誌，29(1992)，434.

9）吉野博之，田谷嘉浩，加賀寿：1994年度粉体 工学会誌秋期研究発表会講演論文集, P109.

10) K. S. Kim, W. E. Baitinger, J. W. Amy and N. Winograd: J. of electron spectroscopy and Related Phenomena, 5(1974), 351.

11）加賀寿, 田谷勀浩, 片山博, 濱口由和：粉体 および粉末冶金，39(1992)，1129.

12）野城清: 第 2 回ホソカワ粉体シンポジュウム, (1991), P1. 